\title{
LAST CHANCE INCORPORATED
}

\section{JASON PINE}

Purchase College, State University of New York

(D) http://orcid.org/0000-0001-8252-9239

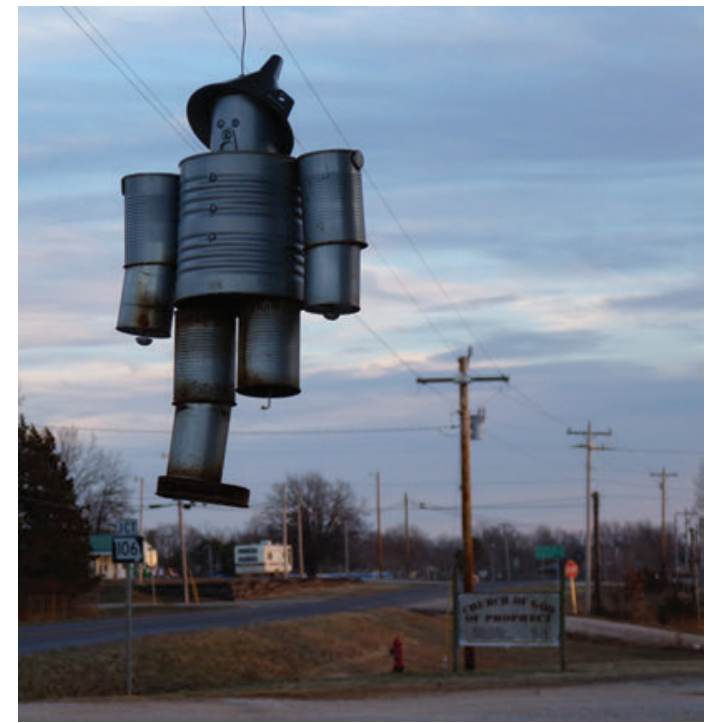

Through industry and ruination, a human body and a landscape compose a life tenuously holding together.

The Monarch trailer lies in the dirt off the side of the road, surrounded by a swarm of objects. A tube lodged in its back issues short, charcoal-black breaths. Tired and heaving. 
A filthy man appears at the door. He descends the stairs, moving with agility. Flapping winter rags trail just behind. The baggy clothes are not hand-me-downs from someone else's life; they once fit him. They slacken, twist and gather up, in sync with the movements of his spindly limbs. Tenaciously holding onto their reverie of a bigger, more robust man - a John Deere or NASCAR man - they ghost him. A figure indistinct like some underimagined protagonist in a fever dream. ${ }^{1}$

An allegorical figure tenuously holding together.

The man pauses when he reaches the ground. He turns his face-a stale dried apple - toward me. His eyes, outrageously magnified by dirty glasses as if to spite his shrunken head, fix on me inquisitively.

Things can go any way. No signboard beckons or welcomes, just the objects. I hitch onto their pulse and let my enthusiasm take over.

"Hey, lots of stuff here. Can I look around?"

"Go on ahead. Everything's for sale except for my tools," says the man toothlessly. He doesn't ask what I'm looking for. He knows I just want to be in the middle of things.

"Why not your tools?"

“Cause that's how I do my work," says the man with a choreographed cadence, unlike the jerking and lurching that carries him off into his thousand-thing garden.

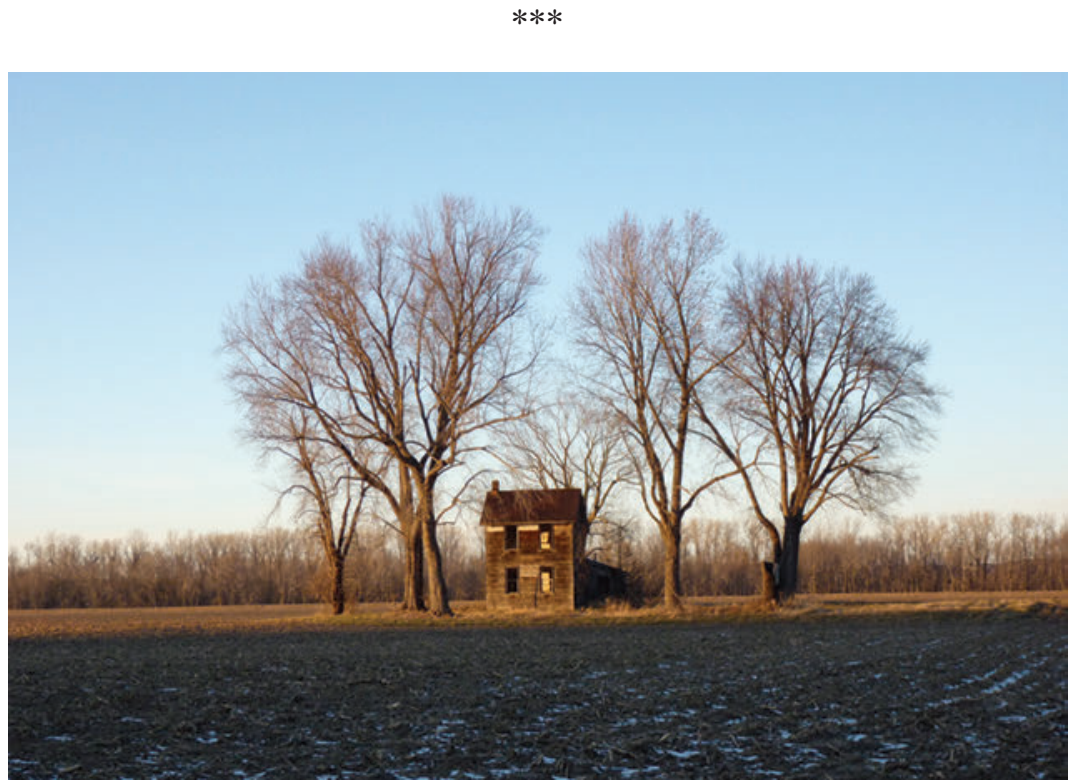

Jesus, hollow and plastic, stands unmoved. 
Winter is warm for January on the edge of Iberia, Missouri. Population 138. Driving unnumbered miles I pass startled bare cottonwoods and pastures of fescue with creeping rootstocks. Cows stare at me, aware. Lone clapboard farmhouses with blind windows stubbornly hold their ground in mud fields. In the town many homes sleep long into the afternoon, not wanting to bother anymore. Santa lies stiff on his back near the front door of a split-level. Jesus, hollow and plastic, stands unmoved. Two houses put in their notice: American Heritage Realty and Sale by Owner. Somewhere a burn pile of sycamore flavors the air.

All of it goes unremarked by Fords and Chevys barreling over asphalt. At the convenience store denim and flannel-clad men in work boots buy beer, cigarettes, and lottery tickets. Sandpaper hands lined with dried grease hold Anheuser-Busch. Women wait in idling vehicles. A cashier receives customers with moderate solicitations, her smile less jubilant than the red-hot mouths that advertise Crunk!!! Energy Stix on the packets that dangle from the counter display rack.

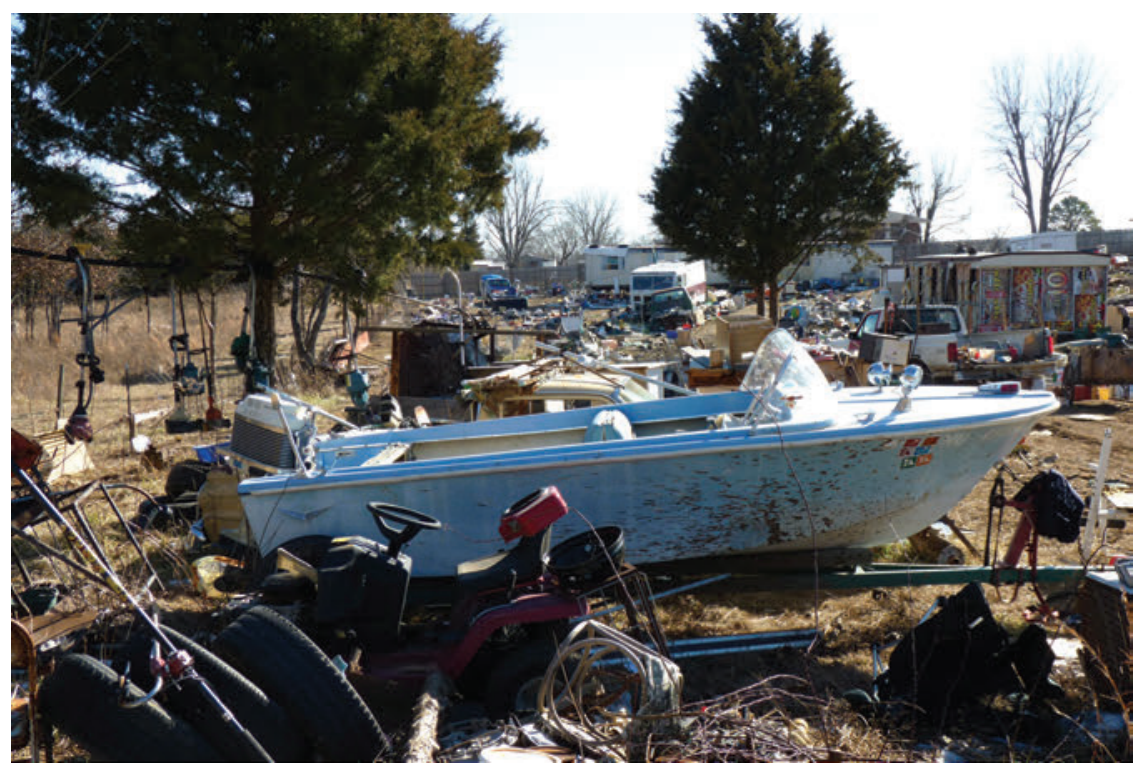

My Fata Morgana.

And beyond the edge of town where the humming motors fade into the hush-hush of the cottonwoods there irrupts all at once . . . abundance! 
It's as if most of the town's objects have shipwrecked here, urged on by some mesmeric charm. In this roadside encampment, the small and the big congregate, exuberant multiples — valve spring and valve spring and valve springplaying counterpoint to the gravitas of monumental singularities: a McCormick Farmall tractor. Textures and densities, liquidities and radiances. ${ }^{2}$ A wild litteracres of objects in heavy rusted iron, thin aluminum, hard bright plastics, corroded steel, damp polyester. Children's toys mix promiscuously with the powerful toys of adults. Spools and wheels of wires and lights. Steel drums filled with nameless hard brittle things.

Aluminum rods and steel spokes touch. Shattered glass and shredded insulation rejoice. The bristling rust pities the soggy lumps of cardboard and cotton. The faded plastics, knowing nothing but their simpleminded delights, giggle idiotically at the hulking, creaking machines. There is agitation, anticipation. My Fata Morgana.

The man zigzags back toward me. "I'm just trying to make a living." Then he veers off into the incomprehensible, pattering across the yard, object relations breaking out everywhere. There are, in fact, assemblies of objects that demonstrate extraordinary levels of articulation. They are expansive, although at times their claims seem exaggerated or altogether far-fetched. General Motors meets headlong, front grill to front grill with Coachmen - an irresolvable collision interminably taking place. Nearby an upholstered armchair lies facedown on top of a humiliated Ford Galaxy. Objects join to produce sense-fictions - provocations to bewilderment and speculation about the sense of their assembly. ${ }^{3}$

At other moments the yard is ebullient. Ten Weedwackers dangle from a tree. The exhilaration of sheer quantities - a barrel of rusted broken coils, a bouquet of mangled garden umbrellas - blurt out expletives, an object-Tourette's. On occasion there is true eloquence - deliberate prosodic structures with meter and repetition. Stacks and upright rows of windows rhyme with screens. Frost King. A huddle of black rubber car tires modulate the pitch. Goodyear. Michelin. A shawl draped over the handlebars of a wheelless lawnmower. Haiku. A decapitated tree trunk leans against the front bumper of a Ford pickup, shouldering none of the burden of the open hood. A battered delivery van halfheartedly declares Designed Kitchens and Interiors. 


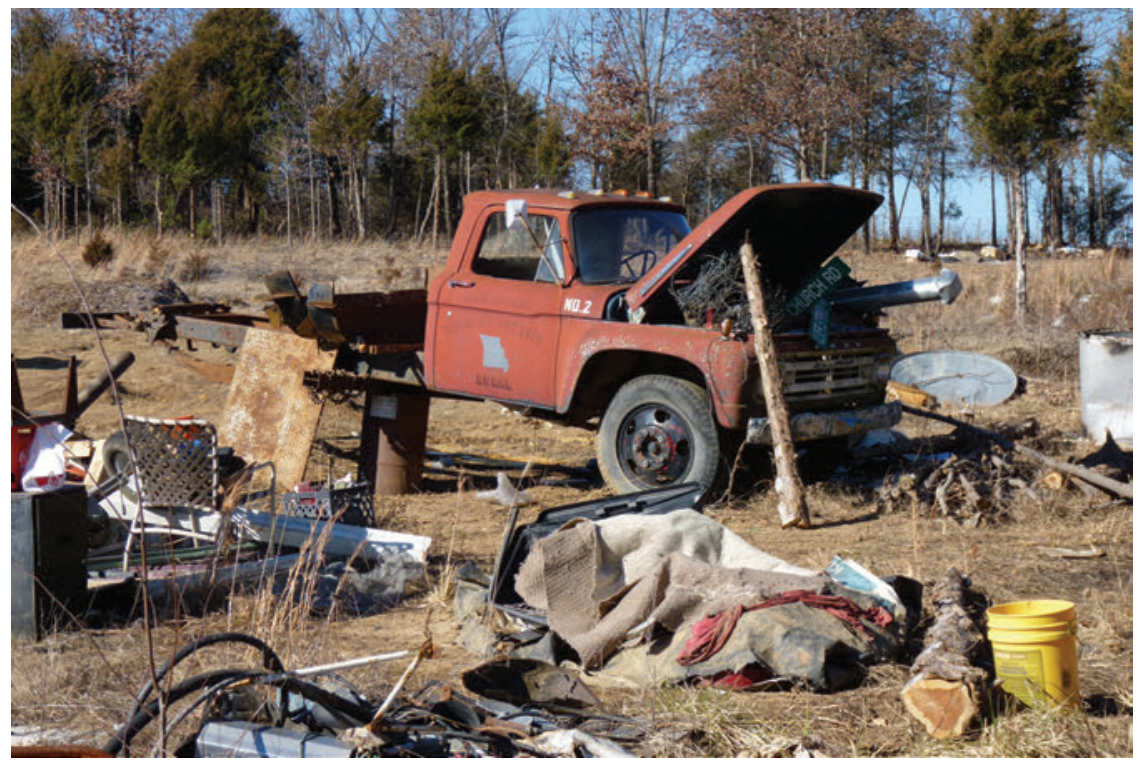

Occulted ways of mattering in a late industrial landscape.

Mattering. 4

I am looking for methamphetamine. When I do fieldwork in the form of a community study in an eastern Missouri county, I don't only connect with poor, white cooks and users, treatment and law-enforcement professionals, and the protagonists of an industrial-chemical apparatus, its proliferating products, and its unassimilable hyperobjects. ${ }^{5}$ I also bond to meth, wherever it is in the field. After years steeped in matters concerning meth in a single county, I have taken up a materialist sensibility for a kind of world-compositioning that for two decades has landscaped much of rural Missouri and other small-town regions in the United States. $^{6}$

Sometimes, when fieldwork doesn't work, I leave the years-long community study I've been carrying out to go on rural dérives. I've spent so much time with tweakers that I think I can sense them in object gatherings and dispersions in any small town anywhere. I'm moved along the passional object terrains they inhabit, and I'm drawn into peculiar augmented psychogeographies, like a contact high. ${ }^{7}$ Meth bonds with the molecular unconscious. ${ }^{8}$ It invites thinking-feeling experimentally, desirously, and I feel the transmutation of matter. I sense occulted ways of mattering in a late industrial landscape.

Meth is worked from the landscapes it embellishes - the secrecy of wooded ridges and the engineered ecology of Monsanto seed-sown plains, the open pits 
of rock quarries and the blast furnace of the primary lead smelter, the commodity castles of Walmart and their surrounding paved flatlands, teetering homes, and wayward crowds of objects, some melted or charred by acid and fire. ${ }^{9}$ Meth is entangled with a more familiar repertoire of industrial and homegrown material arts_-mining, ironwork, cement work, carpentry, cleaning. Meth is a performance enhancer that gives you more hours and motivation. It helps you make ends meet, or better. You get more work out of life.

Meth cooking is late industrial alchemy. Alchemy means to carry to its end something that has not yet been completed. ${ }^{10}$ Among meth cooks, late industrial alchemy is the prevailing way that a body, experience, and a landscape all come to matter. A body is liberated as energy, ${ }^{11}$ experience gets charged with the notyet, and things start taking place. It's the hope of transmutation. Meth is the Philosopher's Stone, the white, yellow or orange-brown powder that can transmute industrial-chemical and mass-consumer base matter into gold. Sudafed. Energizer. Drano. Coleman. Walgreens Instant Cold Packs. No sooner do you hold them in your hand than you appear inspired by them and seem to look through them into their distance, like an augur. ${ }^{12}$ It makes you the Demiurge slowing and speeding the work of production, making your world anew. You get more life.

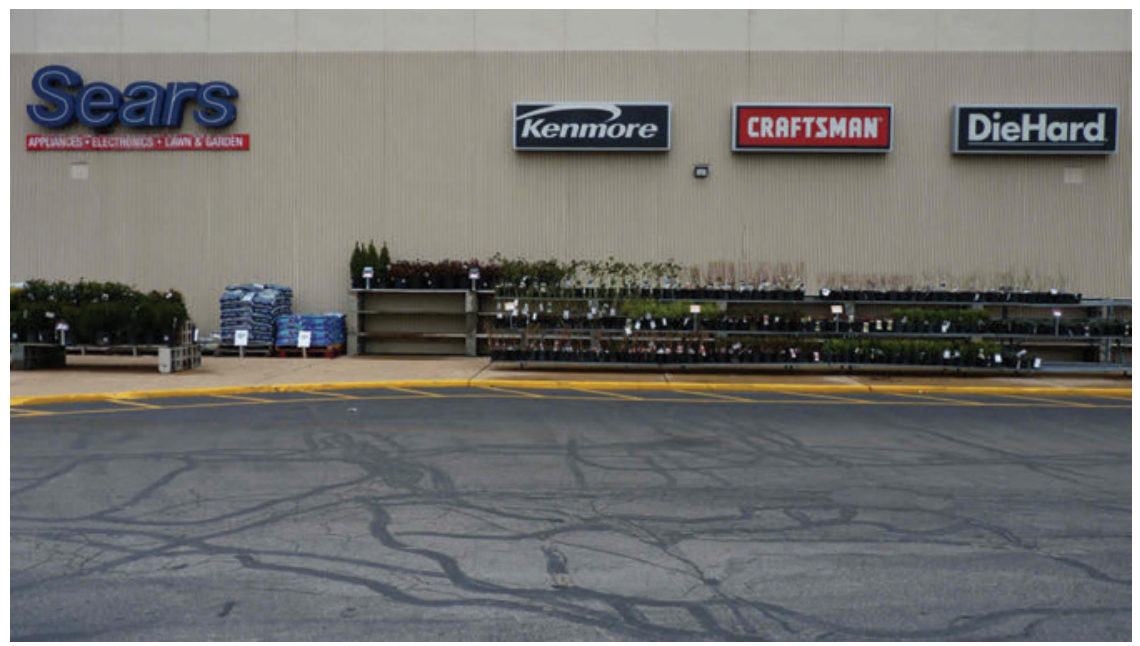

It leads the way out of workaday failures while lapsing back into them. 
Meth cooks in small-town Missouri, like alchemists, take an allegorical approach to their arts. Meth cooks often invoke religious tropes to interpret the ecstatic successes and the catastrophic failures of cooking. Some describe their operations as ministries and their users as parishioners. Some interpret their survival of explosions as God's exhortation to quit and to get others to do the same. Church marquees allude to the struggles of meth addiction or metonymically to the struggles of Post-Fordist Precarity — materialized as landscapes checkered with Dollar Trees and Walmarts, inhabited rundown trailers, piles of objects, and abandoned or unsold homes - and the quandaries of people caught in its throes. God tells them, Tough problems? Strategize less and pray more, and Do not let us mistake necessary evils for good, and Jesus was born for sinners and you qualify. Oscillating between intoxication, withdrawal, detoxification, and abstinence, people associate meth with treacherous sorcery, sacrificial devotion, and righteous religiosity. Occult, evangelical, and mass-consumerist matters mingle promiscuously in an unstable composition.

Allegories are alluring because they promise to light up inchoate objects, trace unimagined connections, and resolve ambiguities and paradoxes of humanand more-than-human and abiotic - life. ${ }^{13}$ At the same time, modern allegories reveal their own failure to cohere. Whereas symbols present themselves as organic forms indivisible from their transcendent ground, allegories disintegrate in the excessive polysemia of their heterogeneous fragments. ${ }^{14}$ Meth cooking similarly throws into relief the unstable composition of a life. Meth cooking is an aporia. It leads the way out of workaday failures while lapsing back into them. ${ }^{15}$

This allegory is inseparable from these objects in this small-town Missouri landscape, but it also points at postindustrial machinic life elsewhere, including Cognitive Capitalism at the academy and the objects proliferated by its theorizing machines. ${ }^{16}$ Concepts pop into mind like consumer products. They are capitalized through observational architectures like citation indices and impact factors, reducing creativity to market shares in attention economies. ${ }^{17}$ Like many academics and students, I use Attention Deficit Disorder amphetamines to be alert to conceptual risks and opportunities. I make jury-rigged constellations with any combination of these objects to access an encounter and its occulted potentials. ${ }^{18}$ Doing ethnography on meth in Missouri feels like a tweaker project.

This ethnographic allegory is not a pastoral about an other America in a present becoming-past, but a tale of desire and dispossession cast in the time of now, when trashed promises of a better life have the possibility of being fulfilled. ${ }^{19}$ 
This time is at turns crystallized and expanded with matters that cannot be contoured to fit progressivist-industrialist or romantic-naturalist narratives.

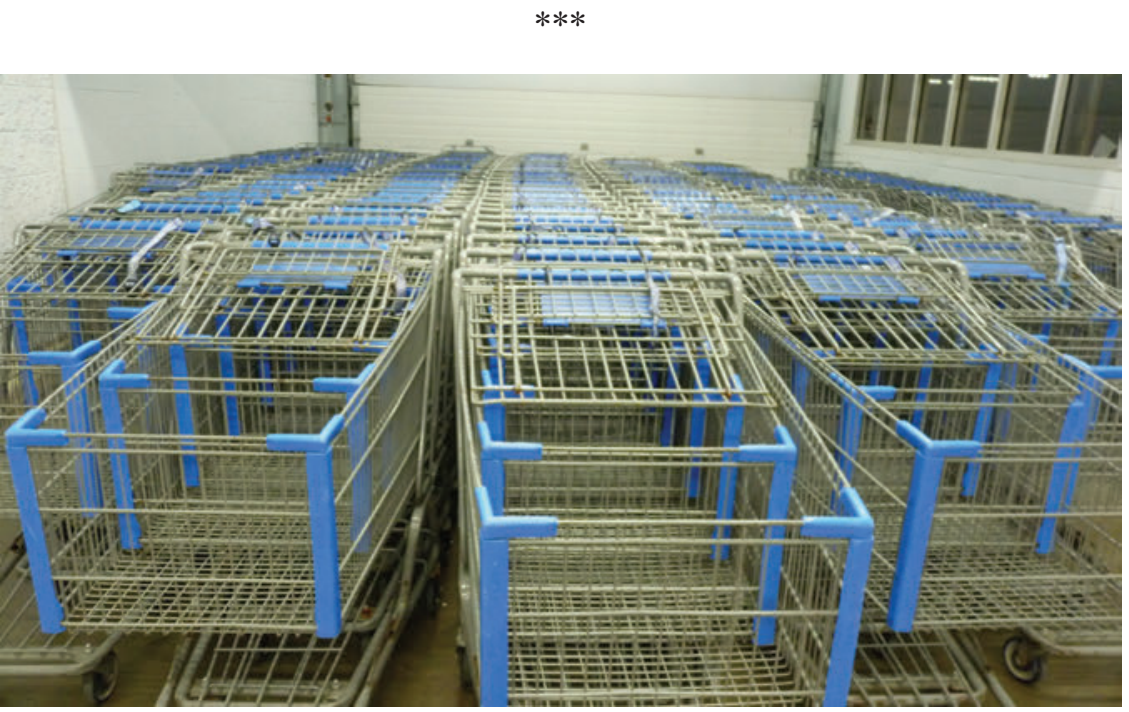

Save Money. Live Better. My Walmart.

When I wayfare in rural Missouri, I cross affective landscapes charged with toxic dreams and precarious compositions. Sometimes I start at Walmart, the largest retailer in the world and the largest private employer in the United States. Walmart reports annual earnings in the tens of billions of dollars. A single Walmart Superstore - hundreds of thousands of cubic feet containing tens of thousands of consumer products like electronics, clothing, foods (generic, brandname, organic), tools, furniture, auto parts, guns, toys, wedding rings, pharmaceuticals - can employ more than five hundred people who can help you service a complete life. Vlasic Pickles. Huggies. Depend.

Long, wide aisles flanked by shelves upon shelves holding rows of objects that repeat flat incantations about life laid out from birth to death. ${ }^{20}$ The repetitions count object time toward a vanishing point, the dwelling place of an unfathomable magnanimous source. ${ }^{21}$

Sam Walton, the late founder of the company, was driven more by competition than by money. Walmart's mission has always been to keep prices low by controlling costs, which Walton achieved by spreading a Benjamin Franklinesque pragmatism guided by industry and frugality. Products are often astonishingly cheaper at Walmart than anywhere else. The company thrives on sales 
volume, operating on a mere 3 percent profit margin. Drawing all things into its hallowed hangars of merchandised life, Walmart has dwarfed the world outside. Competing retailers fail, Walmart's monopsony power grows, and the monolith turns "even its largest suppliers, and entire oligopolized industries, into extensions of itself." 22 Walmart has literally shelved the free market to preside over it. Sam's Club. Shoppers get more for less and, from the point of view of the customer, you want everything. ${ }^{23}$ Save Money. Live Better. My Walmart. ${ }^{24}$

Sudafed. Energizer. Drano. Coleman. Walgreens Instant Cold Packs. ${ }^{25}$ Some shoppers sense in some of the most banal products the promise of metamorphosis in exchange for all-consuming surrender. The products serve methamphetamine synthesis, their sale subject to surveillance and controls. Pseudoephedrine. Lithium. Sulphuric Acid. Ether. Ammonium Nitrate. Meth cooks extract the base elements of late-industrial abiotic life to make the Philosopher's Stone. Emblems. Part-Objects. Transformational Objects. ${ }^{26}$

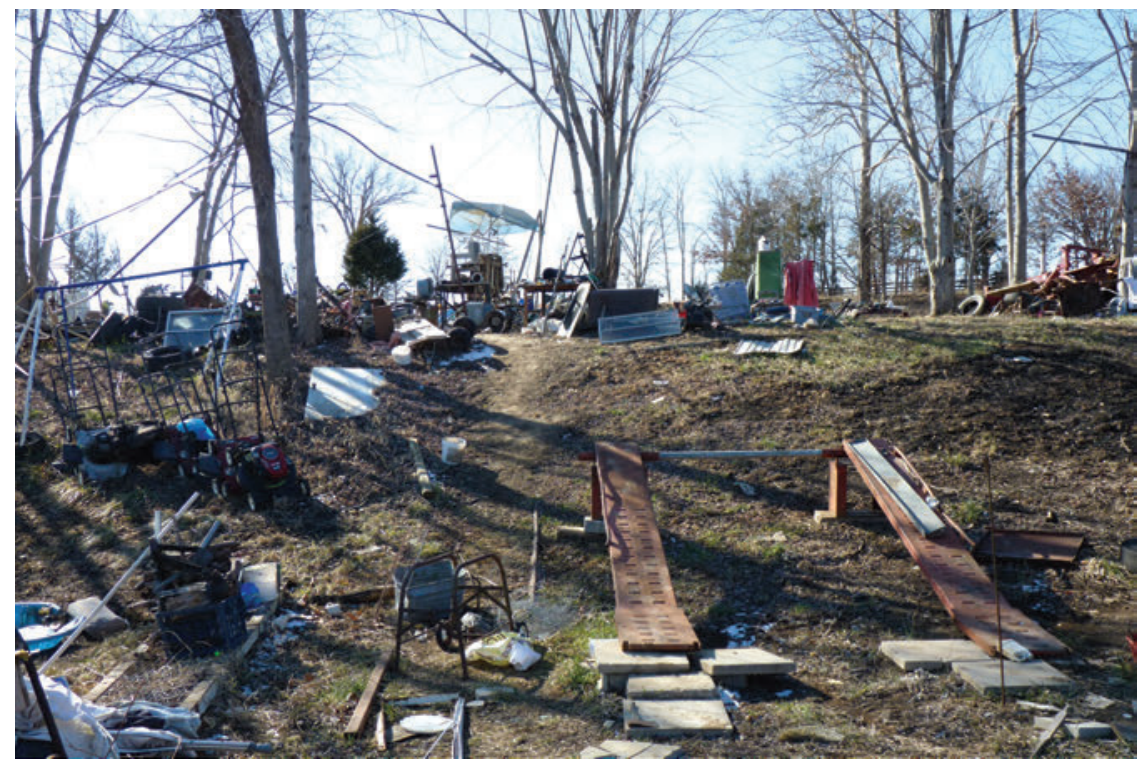

Energy arises from the unrestrained expenditure of energy, and a crystal moment dilates with supernumerary events.

Meth is the center of an alchemical cottage industry where cooks rouse the spirit in everyday products and in the process are themselves transformed. Meth intensifies novelty-seeking and reward-seeking, which is experienced as an anti- 
cipatory high. This feeling is distinct from consummatory pleasure; it is instead the thrilling sense of alertness, heightened interest, motivation, ability, and power that primes the body to forage and seek objects of desire. ${ }^{27}$ Meth activates the seeking system, and in Missouri it fires up bodies to play, fuck, or be more industrious at the factory, construction site, and ironworks. Or in the meth lab, where Walmart products are yet again enlivened, flooding the mesocortical, mesolimbic, and nigrostriatal dopaminergic pathways to dysregulate affect. ${ }^{28}$ Over time the repetitions can yield the ultimate difference machine: schizophrenia. ${ }^{29}$

Desiring-production has no object: it is the production of production. Desiring-production has no subject: a subject is made with each lived state. Desiringproduction feeds Capital's craving for value-extractive innovation. But without an incorporating telos, by being more nervous than system, it leads Capital to the conclusion of its deepest tendency, its own undoing. ${ }^{30}$ In small-town Missouri economies, reined in by the norms of accumulation, the progressive producerconsumer-self-producer routine is Save More. Live Better. You get more for less. But meth cooks reel in a general economy. ${ }^{31}$ Commodities decompose and recombine, routine production-consumption-self-production exceeds itself, energy arises from the unrestrained expenditure of energy, and a crystal moment dilates with supernumerary events. More life. Meth cooks burn up. ${ }^{32}$ Out of joint, time begets prodigal years that grow a thirteenth freak month. ${ }^{33}$

$* * *$

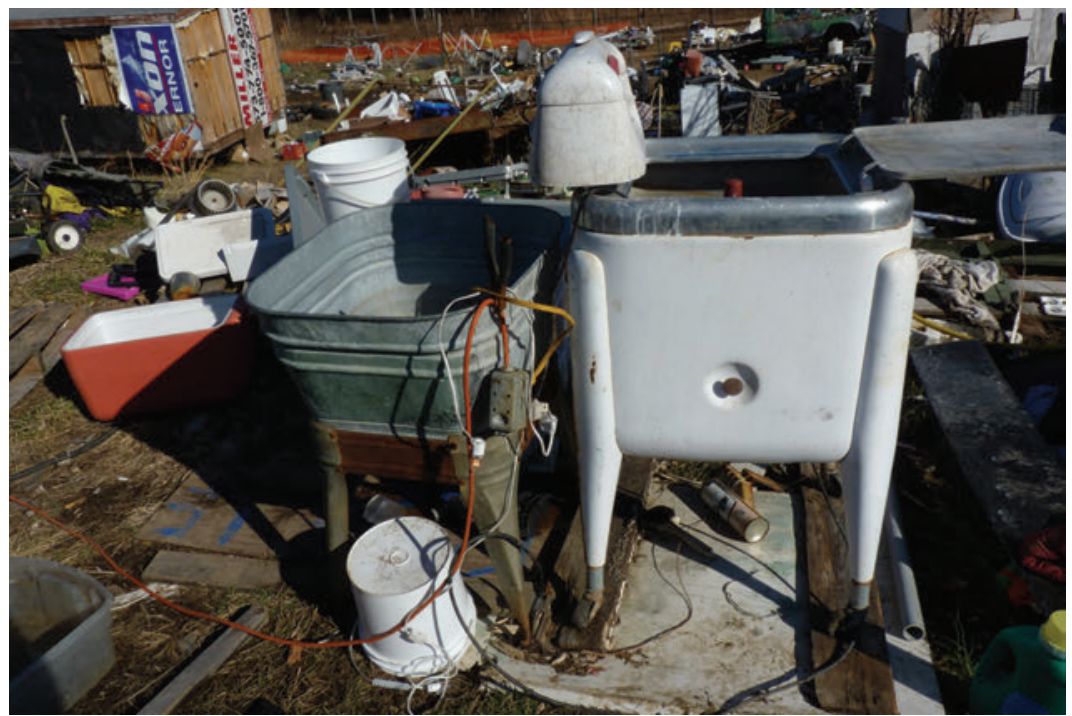

I'll give you five dollars or a thousand dollars to make it work. 
Back outside the trailer, the rattled man looks at me reveling in things. "Last Chance Incorporated," he declares, baptizing the wild litter of objects as his own détourned Walmart. "I'll give you five dollars or a thousand dollars to make it work," he says, mimicking his phantom customers. "That's why I call it Last Chance Incorporated."

Drew, as he tells me he is called, weaves off toward a galvanized steel barrel that has an electrical wire snaking over its rim and down to a generator on the ground. I follow him to the contraption and look inside. Attached to the basin end of the wire is a rusty air conditioner grill, submerged in water. When he jiggles the wire, dark leaden socks stir in liquid copper.

"It's cold water. Gotta heat it and do my warsh."

Meth's alchemical landscapes are often embellished with tweaker projects. When people tweak, they get amped and get onto something - an object of interest or fear, the materiality of an object, or materiality itself - and won't let it go. ${ }^{34}$ They become beside themselves, dispersed across the media that make them. ${ }^{35}$ Objects, especially mechanical devices, fire up exploratory desires that may find their expression in foraging, hoarding, and tinkering, repeated and repeated with nonteleological fervor. Forms of stereotypy characteristic of dopaminergic surging. ${ }^{36}$ Tweaker projects are DIY artifacts, jury-rigged designs that sometimes approach Rube Goldberg machines. The monuments of Desiring Machines. A tweaker project is a bricolage of materials and modalities with - from a mass-consumer perspective — oblique aesthetics of use and uncertain efficacy. ${ }^{37}$ But it holds alchemical promise.

Meth cooks are shade-tree mechanics of all things. ${ }^{38}$ Machinic life. ${ }^{39}$ They perform a détournement of industry, an allegory of late industrial world-compositioning with interchangeably human, more-than-human, and abiotic quasiobjects. ${ }^{40}$ They step up the cycle of mass-production-consumption-self-production and speed toward its ultimate effects. 


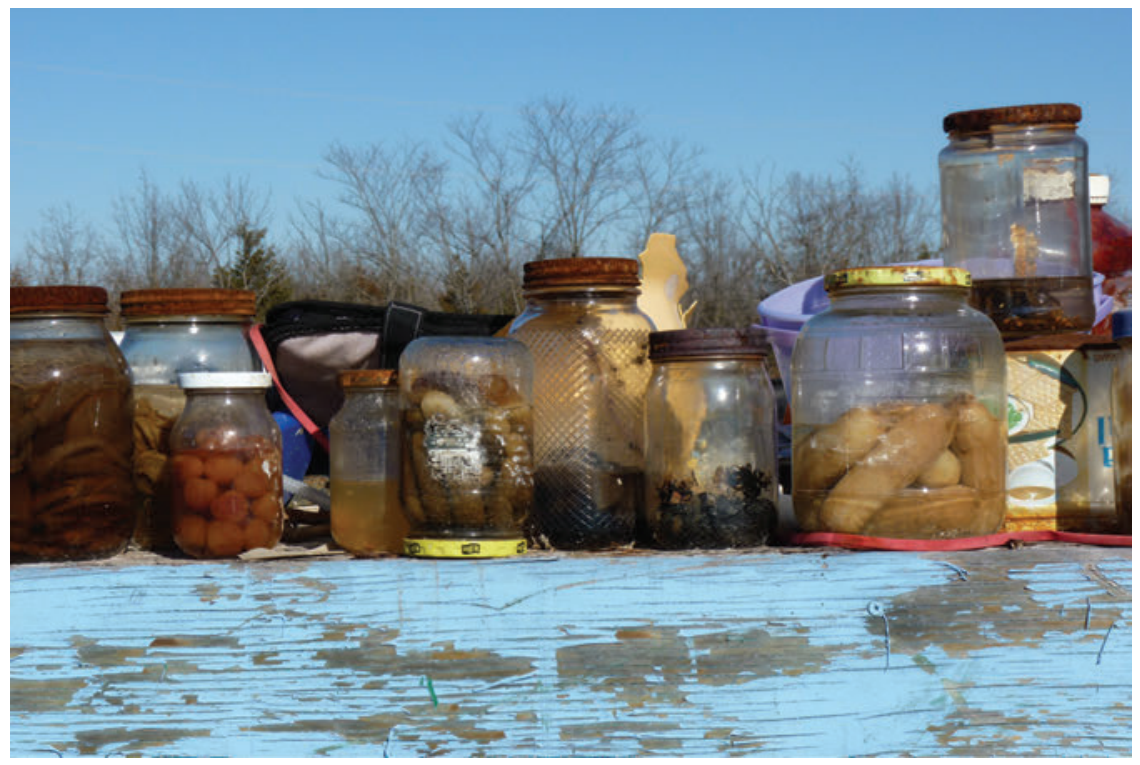

The excrescences of that great garden of arcana.

"You know how to make meth?"

"Well I might know where it is, but I don't know you."

He directs my attention to the jail to our left. Part of the field and its objects are hemmed in by a tall chain-link fence. "It reminds me about prison," says Drew.

Drew comes from the Ozarks, further south by the border with Arkansas. He lived there until he was thrown in prison for seven years. "For cocaine. It's good I remember," he mumbles and then fades into silence.

Suddenly my question returns to him, snapping him out of his reverie. "I like the Shake-and-Bake method. ${ }^{41}$ I got all three ingredients right here, somewhere." He flings a hand at the thing terrain spreading before us. "Let's go over there."

He moves toward the horizon where the lively topography is given over to a macabre setting. Some objects in their arrogant sense of self-importance have taken up playing house. A sofa, La-Z-Boy, TV, and bookcase assume their positions in the remains of a clapboard home. The house bears a wound for a wall and patches of sky where the ceiling was blown off. The furnishings nevertheless insist on conjuring a half-baked reality. They refuse to assist in the conscripting scenarios of JC Penney and Better Homes and Gardens. Instead, they enact a design noir where things — not objects struck dumb-look back at, turn away 
from, or simply ignore people, their ultimate opacity causing puzzlement and sometimes uneasiness. ${ }^{42}$

Outside the house on a paint-scaled retaining wall, bloated generatio aequivoca hold their breath while waiting suspended in a dozen foggy pickling jars. ${ }^{43}$ It seems these formless things are the excrescences of that great garden of arcana. ${ }^{44}$ Culled from the retracted lives of objects, the embers burning somewhere among the parts of vacuum cleaners, Barbies, Chevys. Kenmore.

The objects have broken away from the town's metronomic routine-home, work, store, home, and myriad variations in between - to this halfway house of the untimely. ${ }^{45}$ They flee from a world that still adheres to form and order. ${ }^{46} \mathrm{~A}$ migration of forms. ${ }^{47}$ Larval subjects. ${ }^{48}$

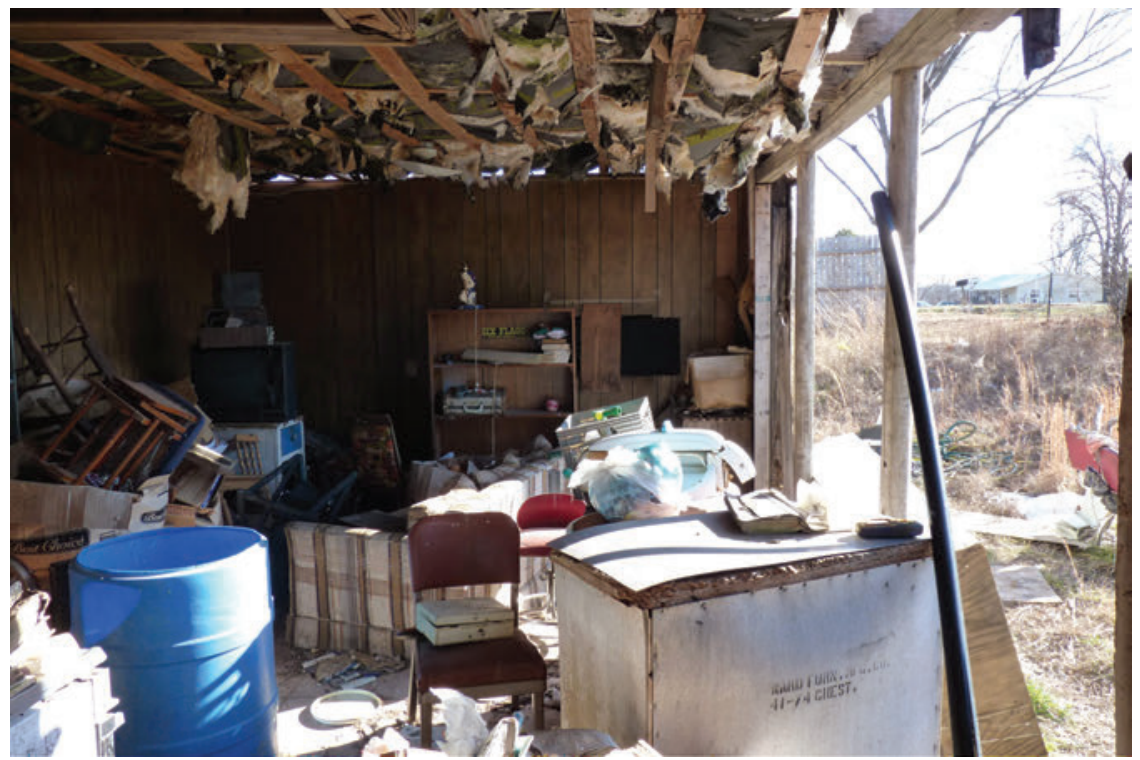

A flickering, imaginal life where objects shimmer, only to slip into slumber once again.

I follow Drew inside. Broken sunlight slashes the living room. He crouches before the moldy plaid sofa. Untwisting a piece of plastic wrap that he produces from a determined fist, he lays out two shaky lines of yellowish powder.

"Meth is good and it's bad." He feels deeply what he's saying. He leans down and snorts one of the lines. Meth blasts a life, freeing it from the metronome of history. ${ }^{49}$ But it's a flickering imaginal life where objects shimmer only to once again slip into slumber, leaving you too dispirited. ${ }^{50}$ 
"I cry like a baby every night. I cry for my momma," says Drew as a drizzle of dopamine wets his receptors. He looks at me with hazy anticipation, waiting for me to snort my line.

Each time desiring-production gives itself over to ecstatic abandon, more life feels as if forever on the threshold of concrescence. Expenditure begets its own energy. A general economy swells. And for a crystal moment . . . until the exuberance is lassoed as addictive consumption, an exaggerated producer-consumer-self-producer desire caught in perpetual ratcheting repetition. ${ }^{51}$ Last Chance Incorporated.

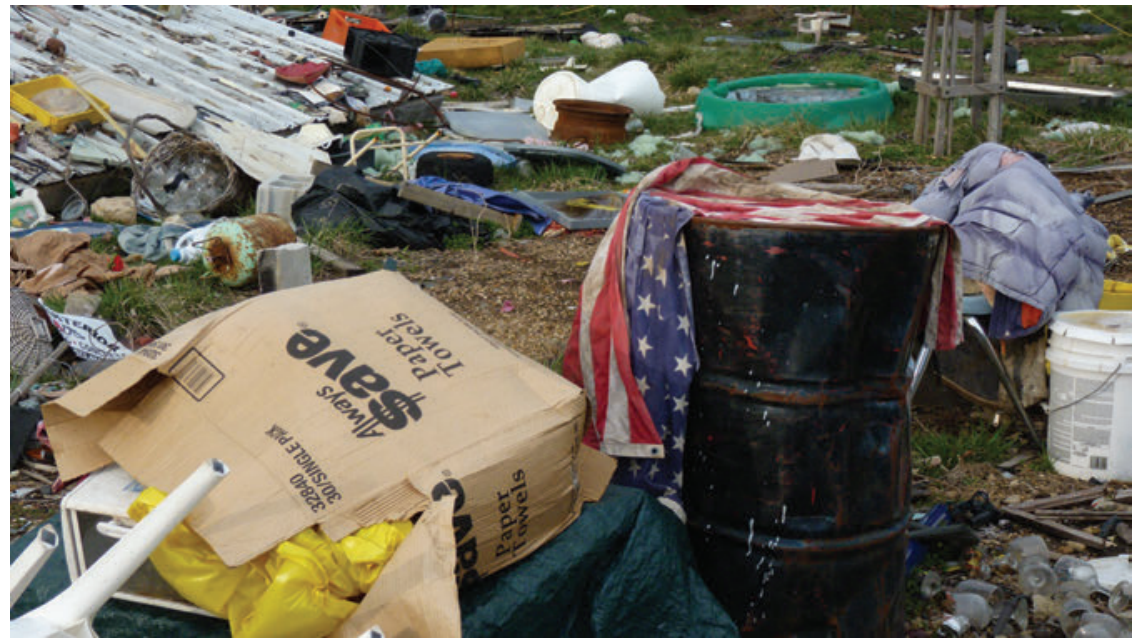

The leavings of late industrialism and a gluttonous accumulation of concepts.

Holding tight with lattice force, the yellowish crystals keep to their crooked line, the one line remaining. My seeking system. When I look for meth, I don't pick my way through the ruins of uneven geographic development, rogue industry, dysregulated consumption, despoilation, and dispossession only to tell an allegorical tale, and certainly not one that makes theory its privileged register and words its privileged marks. ${ }^{52}$

Immersed in a field of objects - the leavings of late industrialism and a gluttonous accumulation of concepts - I am trying to feel my way back, through the unreserved use of metaphors, parataxis, the pathetic fallacy, images and allegory, to a fleeting encounter with a person and a place out of time, yet still here. ${ }^{53}$ This ethnographic allegory is not only textual, but a textualization of an 
already allegorically inscribed material-affective geography. Through industry and ruination, a human body and a landscape compose a life tenuously holding together. ${ }^{54}$ Intermittently fanning the spark of an obsolete hope to hold off getting snuffed out. ${ }^{55}$

I too am sometimes intoxicated with hope-that the alchemical work of redemptive criticism can inscribe an abandoned promise in the lineaments of the present and affect it. ${ }^{56}$ That ethnography can matter. But the thirteenth month only rarely reaches maturity, and like a child conceived late in its mother's life, it lags behind in growth; it is a hunchback month, a half-witted shoot, more tentative than real. ${ }^{57}$

\begin{abstract}
Allegories are alluring because they promise to light up inchoate objects, trace unimagined connections, and resolve ambiguities and paradoxes of human-and morethan-human and abiotic - life. At the same time, allegories reveal their own failure to cohere, disintegrating in the excessive polysemia of their heterogeneous fragments. Meth cooking similarly throws into relief the unstable composition of a life. Meth cooking is an aporia: it leads the way out of workaday failures while lapsing back into them. [affect; allegory; desiring-production; late industrialism; material geography; methamphetamine; object-oriented ontology]
\end{abstract}

\title{
NOTES
}

All photos by Jason Pine.

1. See Gay 2006, 253.

2. See Anderson and Wylie 2009, 326 .

3. Anthony Dunne (2005, 43-45) calls a sense-fiction a design with "para-functionality," that is, it is "within the realms of utility," but it also "embodies provocative or poetic qualities," where individual elements are recognizable but their combination is bewildering.

4. For Karen Barad (2003), mattering is matter-as-phenomena enfolding "to matter" in both its senses in an epistemological and ontological becoming of things. In this case, mattering is also an undoing.

5. A hyperobject, for Timothy Morton (2013), is an object so large and so impinging on human experience that its dimensions are unfathomable yet demand reckoning.

6. Ben Anderson and John Wylie $(2009,3)$ call this a "materialist imagination" based on the principle that "matter potentially takes place with the capacities and properties of any element (i.e., earth, wind, fire, air) and/or any state (i.e., solid, liquid, gaseous). The question of materiality therefore far exceeds any invocation of ground or physicality." Home meth labs are discovered in most parts of the United States. The phenomenon of small-scale production was most concentrated on the West Coast, Hawaii, and in the Midwest before it gradually moved southward and eastward to all the states. Methamphetamine originating from large-scale superlab production comes, since the 1990s, predominantly from Mexico.

7. See Debord 1956. Tweaker is slang for meth user. Passional terrains are Guy Debord's situationist renderings of space through movements of attraction, play, and unregulated 
pleasure - in other words, the live situations of dérives. Additionally, see Ingold 2007; Coole and Frost 2010; Lee and Ingold 2006.

8. Different from stable, representational-structural forms of the higher-order molar level, the dynamic synthesis of the molecular makes molar life possible. For the molecular unconscious, see Deleuze and Guattari 1983, 283-96.

9. Missouri is the location of the Lead Belt, which until recently produced nearly threequarters of the lead used in the United States. Before it closed in 2013, the Doe Run plant in Herculaneum, Missouri was the largest primary lead smelter in the west.

10. See Paracelsus 1999.

11. See Baudrillard 1993, 102.

12. See Benjamin 1999, 207.

13. See Truitt 2015.

14. See Jameson 1986, 73; Benjamin 2003, 56; Kelley 1997, 11.

15. See De Man 1979, 275.

16. Yann Moulier Boutang $(2011,55)$ defines cognitive capitalism as a type of accumulation based on the valorization of knowledge and innovation, writing that "cognitive capitalism produces knowledge by means of knowledge and produces the living by means of the living." André Gorz $(2010,52)$ refers to cognitive capitalism's primary means of production as "self production."

17. As a recent editorial in Urban Geography $(2014,785)$ observed: "When communication and attention are commodified, debates over meaning and significance cannot even take place until 'the market' has allocated a minimum value of the currency (the attention measure purporting to reflect what it helps to create, Heisenberg style) to the matter in question. The quickening cycle of closure between genuine creativity and observational capitalization undermines the historical legitimacy of citation as a means of recognizing others' work and tracing the evolution of ideas, fostering bizarre competitive dynamics in which even the harshest criticism enhances a charlatan's citational stardom.” Thus, the high ranking of Cultural Anthropology might implicate me as a member of the cognitive-capitalist elite.

18. Following Karen Barad (2003, 814), this nonrepresentational approach emphasizes "a causal relationship between specific exclusionary practices embodied as specific material configurations of the world (i.e., discursive practices/(con)figurations rather than 'words') and specific material phenomena (i.e., relations rather than 'things') . . . apparatuses of bodily production and the phenomena produced."

19. See Clifford 1986, 115. For an "Other" America, see Stewart 1996. For the time of now, or now-time (Jetztzeit), when a moment from the past becomes, in a flash, recognizable, outside the narrative of progress, bringing the past into its (belated) timeliness, see Benjamin 1968.

20. In 2009, Walmart began selling coffins and urns online.

21. See Baudrillard 1998. Walter Benjamin might have called this the mythic time produced by capitalism.

22. See Lynn 2006; Fishman 2006.

23. See Walton 1992, 221.

24. Walmart's motto is "save money, live better" and one of its slogans is "my Walmart."

25. These are common products containing the complete array of precursor ingredients needed for making methamphetamine.

26. Transformational objects bear projected desires and in the process are themselves made sacred. See Bollas 1979.

27. Consummatory pleasure refers to pleasure experienced in the midst of enjoyable activity. See Panksepp 2004.

28. Norepinephrine and epinephrine are also involved in the biochemical and physiological effects of methamphetamine; see Zametkin and Rapoport 1987. See also Casper 2006 on the potential relationships between anorexia nervosa, the nor/epinephrine and dopamine systems, the foraging gene, alertness, and the drive for movement - a set of 
relationships suggesting that meth users' reduced food intake may enhance the drug's effects.

29. See Panksepp 2005; Deleuze and Guattari 1983.

30. See Deleuze and Guattari 1983, 35. Elsewhere on the same page: "The schizophrenic deliberately seeks out the very limit of capitalism: he is its inherent tendency brought to fulfillment, its surplus product, its proletariat, and its exterminating angel. He scrambles all the codes and is the transmitter of the decoded flows of desire."

31. On restricted economy and general economy, see Bataille 1991.

32. See Baudrillard 1993, 102. In Georges Bataille's words, this burning up is the nonlogical difference (a difference that is nonoppositional, that is, it undoes oppositions and boundaries) of a general economy that escapes all containment (and freedom/sovereignty that exceeds all control).

33. See Schulz 1977, 125. Time out-of-joint, for Gilles Deleuze and Félix Guattari (1983), refers to the future anterior, arriving at a destination without having taken the journey.

34. See Pine 2014.

35. See Rotman 2008.

36. See Panksepp 2004; Previc 2009. Stereotypy refers to repetitious thought or movement (behavior), a symptom correlated with excessive dopamine levels in the brain.

37. See Dunne 2005.

38. A former eastern Missouri meth cook described, in these terms, his propensity to "fix" things. His wife interjected, "Yeah, but usually it was working when you started."

39. Machinic, in this instance, refers to Gilles Deleuze and Félix Guattari's notion of a difference machine, an assemblage, which George Marcus and Erkan Saka $(2006,103)$ describe as "the causally productive (machinic) result of the intersection of two [or more] open systems."

40. For Frédéric Vandenberghe (2008, 885), capitalism is made machinic "by producing the subjects that produce and consume the products they have produced. . . When subjects are incorporated by the system as components of its own machinery, the subjects have become its living medium and mediation." Michel Serres (1987) writes that quasi-objects are part subject because subjects cannot exist without objects. Bruno Latour $(1993,96)$ writes that quasi-objects and quasi-subjects proliferate in the nonplace between the "Nature pole" and the "Subject pole" where "the work of mediation emerges."

41. In the past decade, a new meth recipe circulated, which required only a few ingredients and a bottle. In 2011 and 2012, so-called Shake-and-Bake labs, in which all the ingredients are mixed in a single bottle, were discovered in two Walmart stores, one in Tulsa, Oklahoma, and the other in Boaz, Alabama. In the Tulsa incident, the culprit stated that she set up shop in the store - using drain cleaner, lithium from AA batteries, and pills containing pseudoephedrine - because she could not afford to buy the ingredients. See Huffington Post 2011, 2012.

42. See Dunne and Raby 2001. For the distinction between the familiarity of objects and the elusiveness of things, see Brown 2001.

43. Generatio aequivoca is the medieval Western theory of spontaneous generation.

44. Matter without form or formless (l'informe) is Georges Bataille's (1985) antiphilosophical base-material emphasis on that which cannot be made to cohere, in both senses of the word. See also Bois and Krauss 1997.

45. Routine movements were the object of the Situationists' active unmaking. Elizabeth Grosz $(2004,11)$, interpreting Friedrich Nietzsche, writes that "the untimely is that which is strong enough, active enough, to withstand the drive of the present to similarity, resemblance, or recognition, for the untimely brings with it the difference that portends the future." Out-of-time difference is also what emerges through repetition, according to Gilles Deleuze (2001a). Paul Rabinow $(2009,27)$ writes that an untimely event is one in which "the things of the actual and existing world can be made into something appropriate as well as inopportune ... appropriate at least retrospectively in that it reconfigures existing things and relations, and inopportune in that it disrupts those existing things and relations and changes their tone, register and directionality." 
Drawing on Deleuze, Rabinow further characterizes an untimely event as a "countermovement."

46. See Gay 2006, 141.

47. Bruno Schulz (1988) explains the transience of form as the "migration of forms."

48. Drawing on Gilles Deleuze's (2001a, especially chapter 2) notion of the larval subject, Levi Bryant (n.d.) writes on his blog that larvae are creatures in formation, which includes "philosophical larvae" that are "without determinate positions or commitments." Kim Fortun $(2012,452)$ argues that these protoformations are possible when "discursive gaps" are addressed and creative responses provoked.

49. See Benjamin 1999, 474.

50. Anhedonia, or the loss of hedonic capacity, including deficits in the reward processes of anticipation, motivation, and reinforcement learning, is associated with dopamine; see Der-Avakian and Markou 2012. Anhedonia is commonly named a symptom of methamphetamine withdrawal and, according to some addiction-treatment professionals, can last for as long as two years, dramatically increasing the likelihood of relapse. Yet this medical explanation of postchronic methamphetamine use can be only part of the story. Often users return to lives that are unfulfilling, and they are unfulfilling precisely because they cannot seem to prime people to anticipate rewards. Catherine Malabou (2012) explores the relationship between biology and the social by way of the connections between neuropathological disaffection, or affective barenness, and disaffiliation, this last a concept developed by Robert Castel (1995) to refer to a social condition of marginalization. Malabou (2012, 157-59) specifically makes the connection to lack of integration in the "work world." Her title, "the new wounded," refers to a new paradigm in which the neurologically wounded are now also considered to be psychically wounded.

51. On addictive consumption, see Reith 2004.

52. The material and moral ruin that troubled Walter Benjamin and his contemporaries in interwar Europe arrived, in a sense, in the United States decades later in late industrial geographies wracked by a different kind of violence, which Kim Fortun $(2014,310)$ describes as the "continuing productivity of industrial culture and desire, with high throughput of consumers who love and depend on toxic products" despite and because of the fusion of "natural, technical, political-economic, social, and discursive systems, all of which are aging, often overwrought, ossified, and politicized."

53. On anthropomorphism, see Bennett 2009, 98-99, who argues that imputing agency to matter is a clumsy and risky way to begin to think and perceive ecologically, throwing into relief isomorphisms across apparent ontological divides. This text also performs what Timothy Morton (2006) might call dark ecomimesis through parataxis (a series of successive independent clauses without coordinating conjunctions) and ekphrasis (rendering in words the qualities of objects and phenomena and the affective force of those qualities) to create the ambience of an ecological noir, as well as what Ian Bogost (2012, 61-67) calls alien phenomenology by way of "exuberant metaphors" that imagine and relate to objects' experience of phenomena. For this last technique, I use the writing of Bruno Schulz as inspiration for his attention to the messianic in worldly disguise in Poland's postwar everyday capitalism. Schulz equates matter with the substance of language and valorizes the imaginative interpretive work of reading as the alchemical work of redemption. To this end, his texts are richly allegorical, embracing an "aesthetics of overfulness" that, rather than providing mere decoration, prepares "the ground for the unexpected metamorphosis of reality" (Underhill 2011a, 149). I also draw from Don Delillo (1985), who amplifies the "white noise" of uncorrelated information and commodity incantations. The allegory offered here exaggerates "the overdeterminations of description" (i.e., "theory" and "poetics"; see Fortun 2012, 452-53) with the hope of addressing a discursive gap and provoking new ways to respond to it.

54. "A life," for Deleuze (2011b, 29), "is everywhere, in all the moments that a given living subject goes through and that are measured by given lived objects: an immanent life carrying with it the events of singularities that are merely actualized in subjects and 
objects." On landscape as a site for gathering up and dispersal, see Rose 2006 and Wylie 2009 , respectively.

55. See Benjamin 1968, 255.

56. See Löwy 2005, 41. For an elaboration of the connection that Walter Benjamin makes between alchemy and redemptive criticism, or the arrest of historical time by addressing objects piled up in the detritus of history to critique that history, see Rabinbach 1985; Underhill 2011a, 2011b.

57. See Schulz 1977, 125.

\section{REFERENCES}

Anderson, Ben, and John Wylie

2009 “On Geography and Materiality." Environment and Planning A 41, no. 2: 318-35. http://dx.doi.org/10.1068/a3940.

Barad, Karen

2003 "Posthumanist Performativity: Toward an Understanding of How Matter Comes to Matter." Signs: Journal of Women in Culture and Society 28, no. 3: 801-31.

Bataille, Georges http://dx.doi.org/10.1086/345321.

1985 “Formless." In Visions of Excess: Selected Writings, 1927-1939, translated and edited by Alan Stoekl, 31. Minneapolis: University of Minnesota Press.

1991 The Accursed Share: An Essay on General Economy, Volume 1. Translated by Robert Hurley. New York: Zone Books. Originally published in 1949.

Baudrillard, Jean

1993 “The Fate of Energy." In The Transparency of Evil: Essays on Extreme Phenomena, 100-105. Translated by James Benedict. New York: Verso.

1998 The Consumer Society: Myths and Structures. Translated by Chris Turner. Thousand Benjamin, Walter Oaks, Calif.: Sage. Originally published in 1970.

1968 "Theses on the Philosophy of History." In Illuminations: Essays and Reflections, translated by Harry Zohn and edited by Hannah Arendt, 253-64. New York: Schocken.

1999 The Arcades Project. Translated by Howard Eiland and Kevin McLaughlin. Cambridge, Mass: Harvard University Press.

2003 The Origin of German Tragic Drama. Translated by John Osborne. New York: Verso. Originally published in 1928.

Bennett, Jane

2009 Vibrant Matter: A Political Ecology of Things. Durham, N.C.: Duke University Press. Bogost, Ian

2012 Alien Phenomenology, or, What It's Like to Be a Thing. Minneapolis: University of Minnesota Press.

Bois, Yve-Alain, and Rosalind E. Krauss

1997 Formless: A User's Guide. New York: Zone Books.

Bollas, Christopher

1979 “The Transformational Object.” International Journal of Psychoanalysis 60, no. 1: 97-107.

Brown, Bill

2001 “Thing Theory.” Critical Inquiry 28, no. 1: 1-22. http://www.jstor.org/stable/ 1344258 .

Bryant, Levi

n.d. “About.” Larval Subjects. http://larvalsubjects.wordpress.com/about/.

Casper, Regina C.

2006 “The 'Drive for Activity' and 'Restlessness' in Anorexia Nervosa: Potential Pathways." Journal of Affective Disorders 92, no. 1: 99-107. http://dx.doi.org/ 10.1016/j.jad.2005.12.039. 
Castel, Robert

1995 Les métamorphoses de la question sociale. Paris: Gallimard.

Clifford, James

1986 “On Ethnographic Allegory." In Writing Culture: The Poetics and Politics of Ethnography, edited by James Clifford and George E. Marcus, 98-121.

Coole, Diana, and Samantha Frost

2010 "Introducing the New Materialisms." In New Materialisms: Ontology, Agency, and Politics, edited by Diana Coole and Samantha Frost, 1-45. Durham, N.C.: Duke University Press.

De Man, Paul

1979 Allegories of Reading: Figural Language in Rousseau, Nietzsche, Rilke, and Proust. New Haven, Conn.: Yale University Press.

Debord, Guy

1956 “Theory of the Dérive." Translated by Ken Knabb. Situationist International Online.

Deleuze, Gilles http://www.cddc.vt.edu/sionline/si/theory.html.

2001a Difference and Repetition. Translated by Paul Patton. New York: Columbia University Press. Originally published in 1968.

2001b "Immanence: A Life." In Pure Immanence: Essays on a Life, translated by Anne Boyman, 25-33. New York: Zone Books.

Deleuze, Gilles, and Félix Guattari

1983 Anti-Oedipus: Capitalism and Schizophrenia. Translated by Robert Hurley, Mark Seem, and Helen R. Lane. Minneapolis: University of Minnesota Press.

Delillo, Don Originally published in 1972 .

1985 White Noise. New York: Viking.

Der-Avakian, Andre, and Athina Markou

2012 "The Neurobiology of Anhedonia and Other Reward-Related Deficits." Trends in Neurosciences 35, no. 1: 68-77. http://dx.doi.org/10.1016/j.tins.2011.11.005.

Dunne, Anthony

2005 Hertzian Tales: Electronic Products, Aesthetic Experience, and Critical Design. Cambridge, Mass.: MIT Press. Originally published in 1999.

Dunne, Anthony, and Fiona Raby

2001 Design Noir: The Secret Life of Electronic Objects. Basel: Birkhäuser.

Fishman, Charles

2006 The Wal-Mart Effect: How the World's Most Powerful Company Really Works - and How It's Transforming the American Economy. New York: Penguin.

Fortun, Kim

2012 “Ethnography in Late Industrialism.” Cultural Anthropology 27, no. 3: 446-64. http:/ /dx.doi.org/10.1111/j.1548-1360.2012.01153.x.

2014 "From Latour to Late Industrialism." HAU: Journal of Ethnographic Theory 4, no.

Gay, William

1: 309-29. http://dx.doi.org/10.14318/hau4.1.017.

2006 Twilight: A Novel. San Francisco: MacAdam/Cage.

Gorz, André

2010 The Immaterial. Translated by Chris Turner. New York: Seagull Books.

Grosz, Elizabeth

2004 In the Nick of Time: Politics, Evolution, and the Untimely. Durham, N.C.: Duke University Press.

Huffington Post

2011 "Alisha Halfmoon, Tulsa Woman, Accused of Trying to Cook Meth - in Walmart." December 9. http://www.huffingtonpost.com/2011/12/09/ methwalmart_n_1139183.html. 
2012 "Walmart Meth Lab: Custodial Worker Discovers Drug Production in Alabama Store.” April 12. http://www.huffingtonpost.com/2012/04/12/walmartmethlab-boazalabama_n_1421049.html.

Ingold, Tim

2007 Lines: A Brief History. New York: Routledge.

Jameson, Fredric

1986 "Third-World Literature in the Era of Multinational Capitalism." Social Text, no. 15: 65-88. http://dx.doi.org/10.2307/466493.

Kelley, Theresa M.

1997 Reinventing Allegory. New York: Cambridge University Press.

Latour, Bruno

1993 We Have Never Been Modern. Translated by Catherine Porter. Cambridge, Mass.:

Harvard University Press. Originally published in 1991.

Lee, Jo, and Tim Ingold

2006 "Fieldwork on Foot: Perceiving, Routing, Socialising." In Locating the Field: Space, Place, and Context in Anthropology, edited by Simon Coleman and Peter Collins, Löwy, Michael 67-86. London: Berg.

2005 Fire Alarm: Reading Walter Benjamin's "On the Concept of History." Translated by Chris Turner. New York: Verso.

Lynn, Barry C.

2006 "Breaking the Chain: The Anti-Trust Case Against Walmart." Harper's, July: 2936. http://harpers.org/archive/2006/07/breaking-the-chain/ .

Malabou, Catherine

2012 The New Wounded: From Neurosis to Brain Damage. Translated by Steven Miller. Bronx, N.Y.: Fordham University Press. Originally published in 2007.

Marcus, George E., and Erkan Saka

2006 “Assemblage." Theory, Culture \& Society 23, nos. 2-3: 101-109. http:// dx.doi.org/10.1177/0263276406062573.

Morton, Timothy

2006 Ecology Without Nature: Rethinking Environmental Aesthetics. Cambridge, Mass: Harvard University Press.

2013 Hyperobjects: Philosophy and Ecology after the End of the World. Minneapolis: University of Minnesota Press.

Moulier Boutang, Yann

2011 Cognitive Capitalism. Translated by Ed Emery. Malden, Mass.: Polity. Panksepp, Jaak

2004 Affective Neuroscience: The Foundations of Human and Animal Emotions. New York: Oxford University Press.

2005 "Affective Consciousness: Core Emotional Feelings in Animals and Humans." Consciousness and Cognition 14, no. 1: 30-80. http://dx.doi.org/10.1016/ j.concog.2004.10.004.

Paracelsus

1999 "Labyrinthus medicorum errantium." In Paracelsus, selected and translated by Nicholas Goodrick-Clarke, 101-104. Berkeley, Calif.: North Atlantic Books. Originally published in 1538 .

Pine, Jason

2014 “Tweaker Projects." Seachange 5: 11-21. http://www.seachangejournal.ca.

Previc, Fred H.

2009 The Dopaminergic Mind in Human Evolution and History. New York: Cambridge University Press.

Rabinbach, Anson

1985 "Between Enlightenment and Apocalypse: Benjamin, Bloch, and Modern German Jewish Messianism." New German Critique 34, no. 46: 78-124. http:// dx.doi.org/10.2307/488340. 
Rabinow, Paul

2009 “Foucault's Untimely Struggle: Toward a Form of Spirituality." Theory, Culture \& Society 26, no. 6: 25-44. http://dx.doi.org/10.1177/0263276409347699.

Reith, Gerda

2004 "Consumption and Its Discontents: Addiction, Identity, and the Problems of Freedom.” British Journal of Sociology 55, no. 2: 283-300. http://dx.doi.org/ 10.1111/j.1468-4446.2004.00019.x.

Rose, Mitch

2006 "Gathering 'Dreams of Presence': A Project for the Cultural Landscape." Environment and Planning D 24, no. 4: 537-54. http://dx.doi.org/10.1068/ d391t.

Rotman, Brian

2008 Becoming Beside Ourselves: The Alphabet, Ghosts, and Distributed Human Being. Durham, N.C.: Duke University Press.

Schulz, Bruno

1977 The Street of Crocodiles. Translated by Celina Wieniewska. New York: Penguin. Originally published in 1934.

1988 “An Essay for S. I. Witkiewicz." In Letters and Drawings of Bruno Schulz, with Selected Prose, translated by Walter Arndt and edited by Jerzy Ficowski, 110-

Serres, Michel 14. New York: Harper and Row.

1987 Statues: Le second livre des fondations. Paris: François Bourin.

Stewart, Kathleen

1996 A Space on the Side of the Road: Cultural Poetics in an "Other" America. Princeton, N.J.: Princeton University Press.

Truitt, E. R.

2015 Medieval Robots: Mechanism, Magic, Nature, and Art. Philadelphia: University of Pennsylvania Press.

Underhill, Karen C.

2011a "Bruno Schulz and Jewish Modernity." PhD dissertation, University of Chicago.

2011 b "Next Year in Drohobych: On the Uses of Jewish Absence." East European Politics and Societies 25, no. 3: 581-96. http://dx.doi.org/10.1177/ 0888325410388270 .

Urban Geography

2014 "Please Do Not Cite This Article." Unsigned editorial. 35, no. 6: 783-87. http: / /dx.doi.org/10.1080/02723638.2014.949122.

Vandenberghe, Frédéric

2008 "Deleuzian Capitalism." Philosophy and Social Criticism 34, no. 8: 877-903. http: / /dx.doi.org/10.1177/0191453708095696.

Walton, Sam

1992 Made in America: My Story. New York: Doubleday.

Wylie, John

2009 "Landscape, Absence, and the Geographies of Love." Transactions of the Institute of British Geographers 34, no. 3: 275-89. http://dx.doi.org/10.1111/j.14755661.2009.00351.x.

Zametkin, Alan J., and Judith L. Rapoport

1987 "Noradrenergic Hypothesis of Attention Deficit Disorder With Hyperactivity: A Critical Review." In Psychopharmacology: The Third Generation of Progress, edited by Herbert Y. Meltzer, 837-47. New York: Raven. 